\title{
A STUDY OF CYTOKINE CONTENT IN THE BLOOD SERUM OF PATIENTS WITH LICHEN RUBER PLANUS
}

\author{
Nadiia B. BRODOVSKA ${ }^{1}$, Olha I. DENYSENKO ${ }^{1 凶}$ \\ ${ }^{1}$ Department of Dermatoveneorology, Higher State Educational Establishment of Ukraine „Bukovinian \\ State Medical University" (BSMU), Chernivtsi, Ukraine \\ Received 11 June 2018 , Accepted 25 July 2018 \\ https://doi.org/10.31688/ABMU.2018.53.3.06
}

\begin{abstract}
Introduction. Lichen ruber planus (LRP) is a chronic multifactorial dermatosis characterized by skin deterioration, intensive itchiness, and resistance to therapy. It leads to long term patient disability, therefore the main objective of the management is to define the pathogenetic factors of LRP, with the purpose of treatment optimization.
\end{abstract}

The objective of this study was to determine and analyze the level of individual cytokines in blood serum of patients with lichen ruber planus with different clinical symptoms of dermatosis.

Material and methods. The study involved $37 \mathrm{pa}-$ tients with lichen ruber planus. In 20 patients with LRP the pathology of the skin was widespread, and in 17 patients it was limited and localized. In 19 patients the dermatosis lasted for up to 6 months, in the remaining 18 patients - for more than 6 months. In patients with LRP, blood serum concentrations of individual cytokines - tumor necrotic factor- $\alpha$ (TNF- $\alpha$ ), interleukin-1 $\beta$ (IL-1 $\beta$ ), interleukin-4 (IL-4) and interleukin-10 (IL-10) were determined by immunoassay analysis.

Results. It has been found that in blood serum of patients with LRP there is a significant increase of TNF- $\alpha$ and IL-1 $\beta$, a mild increase of IL-4 and a tendency to

\section{Résumé}

Investigation du contenu en cytokines dans le sérum de patients atteints de lichen plan rouge

Introduction. Le lichen plan rouge (LPR) est une dermatose multifactorielle chronique qui, ces dernières années, est caractérisée par des lésions cutanées étendues, des démangeaisons intenses, une résistance au traitement, ce qui entraîne une incapacité prolongée des patients. A cet égard, la tâche importante de la dermatologie moderne est de déterminer les facteurs pathogéniques de la LPR afin d'optimiser le traitement de cette dermatose.

Le but de cette étude est de déterminer et d'analyser le niveau des cytokines individuelles dans le sérum de patients atteints de lichen plan rouge avec différents cours cliniques de dermatoses.

Matériel et méthodes. Une enquête auprès de 37 patients atteints de lichen plan rouge a été réalisée. Chez 20 patients avec lichen plan rouge, le procès pathologique sur la peau était répandu, chez 17 -il était limité. Chez 19 patients, la dermatose a duré jusqu'à 6 mois, dans les 18 restants - plus de 6 mois. Chez les patients atteints de LPR, l'analyse des immunoenzymes a montré la teneur sérique de cytokines individuelles - facteur nécrotique tumoral $\alpha$ (TNF- $\alpha$ ), 
decrease in IL-10 comparing to the control group. Significant changes in the content of the cytokines in the blood serum were observed for the patients with a widespread form of lichen ruber planus and the duration of the disease for more than 6 months, comparing to those with limited forms of the dermatosis and duration of the disease for up to 6 months.

Conclusions. In patients with LRP, changes of the indicators of cytokine profile in the peripheral blood were observed. There was a significant increase in the level of proinflammatory cytokines (TNF- $\alpha$, IL-1 $\beta$ ), and only a mild increase or the tendency to decrease in the levels of anti-inflammatory cytokines IL-4 and IL-10, respectively. The magnitude of these changes of cytokines was dependent on the nature of the clinical progression of the LRP. This finding indicates the significance of the cytokines in the regulation of inflammatory processes in the pathogenesis of LRP. These findings report the importance in examining levels of pro- and anti-inflammatory cytokines, as a criteria in the clinical evaluation of LRP and the effectiveness of its treatment.

Keywords: lichen ruber planus, clinical course, cytokines.

Abbreviations: LRP - Lichen Ruber Planus; TNF- $\alpha$ Tumor Necrosis Factor- $\alpha$; IL - Interleukin.

\section{INTRODUCTION}

Lichen ruber planus (LRP) is a common chronic dermatosis from the group of lichen skin diseases, which presents as a monomorphic rash in the form of typical polygonal shiny papules, with umbilication in the center and severe itching ${ }^{1,2}$.

According to clinical observations, this dermatosis is characterized by widespread skin lesions and lesions of the mucous membranes of the mouth and genitals, severe itching, protracted clinical course, the formation of resistance to treatment in patients, which has a negative effect on the psycho-emotional state of the patients, reduces their ability to work and social activity ${ }^{3-6}$. Therefore, an important task of modern dermatology is to study the pathogenetic factors of the complicated clinical course of LRP and optimization of its treatment ${ }^{7-9}$. interleukine-1 $\beta$ (IL-1 $\beta)$, interleukine-4 (IL-4) et interleukine-10 (IL-10).

Résultats. Il a été établi que dans le sérum sanguin des patients atteints de LPR, il y a une augmentation probable par rapport au groupe témoin du TNF- $\alpha$ et une augmentation de la teneur en IL-1 $\beta$ dans la tendance à augmenter légèrement la IL-4 et la tendance à l'IL-10. Les modifications les plus significatives du contenu des cytokines étudiées dans le sérum sanguin des patients atteints du SNC avec un trouble cutané commun et la durée de la maladie pendant plus de 6 mois comparées aux formes limitées de dermatose et la durée de la maladie sont inférieures à 6 mois.

Conclusions. Chez les patients avec des changements de LPR on a établi dans le profil de cytokines du sang périphérique - une augmentation significative du taux de cytokines pro-inflammatoires (TNF-a, IL-1 $\beta$ ) par seulement une tendance à augmenter ou diminuer les niveaux de direction des cytokines inflammatoires (IL-4 et IL-10). La dépendance de la cytokine étudiée change la nature de la LPR de l'évolution clinique, ce qui indique la cytokine de niveau d'importance de régulation de l'inflammation dans la pathogenèse de la dermatose et l'importance de déterminer le niveau des cytokines sériques de direction pro- et anti-inflammatoires comme les critères d'évolution clinique et d'efficacité du traitement du LPR.

Mots-clés: lichen plan rouge, évolution clinique, cytokines.

Abréviations: LPR - lichen plan rouge, TNF- $\alpha$ Facteur de nécrose tumorale; IL - Interleukine.

The mechanisms of the development of LRP remain unclear. This dermatosis is considered as a multifactorial skin disease, which appears as a result of the complex influence of exogenous and endogenous factors, among which the stress and the psycho-emotional dysfunctions are of importance, the presence of chronic viral and bacterial infection, disorders of neuroendocrine and immune regulation, concomitant digestive diseases, an imbalance of the prooxidant- antioxidant homeostasis with the formation of oxidative stress, etc ${ }^{10-13}$.

At the same time, in recent years, increasing attention of researchers is focused on determining the nature of changes and pathogenetic role of inflammatory mediators (cytokines) in chronic dermatoses. Cytokines are the regulators of intercellular interaction, and are involved in the immune response $e^{14-17}$. The data about the indicators of the cytokine profile in patients with LRP are limited, and are available 
Table 1. Indicators of cytokines in blood serum of patients with LRP $(\mathrm{M} \pm \mathrm{m})$

\begin{tabular}{cccc}
\hline Index, Unit & $\begin{array}{c}\text { Control group, } \\
n=16\end{array}$ & Patients with LRP, $n=37$ & $p$ \\
\hline Tumor necrosis factor $-\alpha, \mathrm{pg} / \mathrm{mL}$ & $6.21 \pm 1.18$ & $9.86 \pm 1.03$ & $\mathrm{p}=0.042$ \\
\hline Interleukin-1 $\beta, \mathrm{pg} / \mathrm{mL}$ & $4.23 \pm 0.51$ & $5.81 \pm 0.46$ & $\mathrm{p}=0.047$ \\
\hline Interleukin-4, $\mathrm{pg} / \mathrm{mL}$ & $3.77 \pm 0.43$ & $4.14 \pm 0.37$ & $\mathrm{p}=0.57$ \\
\hline Interleukin-10, $\mathrm{pg} / \mathrm{mL}$ & $8.25 \pm 1.09$ & $7.59 \pm 0.93$ & $\mathrm{p}=0.68$ \\
\hline
\end{tabular}

Note: $\mathrm{p}$ - the probability of a difference in the indicators relatively to the control group.

mainly for the localization of the pathological process on the mucous membranes of the oral cavity ${ }^{18-21}$.

The obJective of THE Study was to determine and analyze the level of individual cytokines in blood serum of patients with LRP, with different clinical course of the dermatosis.

\section{Material AND Methods}

The study involved 37 patients with LRP, 21 women and 16 men, aged between $19-76$ years, who were treated between 2015 and 2017 in the Regional Dermatoveneorological Hospital of Chernivtsi, Ukraine. All patients signed an informed consent to participate in the study. In all patients, clinical and laboratory examinations have been performed. The patients with LRP with extensive lesions were hospitalized in the Regional Dermatovenerological Hospital, and the patients with limited lesions were treated in ambulatory. All patients were treated by the same dermatologist.

The criteria for inclusion in the study were the following: the presence of clinical manifestations of LRP, the absence of chronic somatic diseases or their exacerbations at the time of examination of patients, the absence of smoking and drinking habits, the consent of the patient to participate in the study. The exclusion criteria from the study were: the presence of somatic diseases or their exacerbations at the time of examination of patients, the presence of smoking or drinking habits, the refusal of the patient to participate in the study.

In 20 patients $(54.1 \%)$ with LRP, the pathology of the skin was widespread in nature, and in 17 patients (45.9\%) it was limited and localized. In 19 patients (51.4\%), the dermatosis lasted for up to 6 months, while in the remaining $18(48.6 \%)$ it lasted for more than 6 months.

In patients with LRP, the concentration of the following proinflammatory and anti-inflammatory cytokines in blood serum was determined: tumor necrosis factor- $\alpha$ (TNF- $\alpha$ ), interleukin-1 $\beta$ (IL-1 $\beta$ ), interleukin-4 (IL-4) and interleukin-10 (IL-10). The study used an enzyme-linked immunoadsorbent assay.

The control group consisted of 16 healthy individuals (donors) of the same age and sex.

Statistical analyses in this study were conducted using MS Excel and STATISTICA 6.0 software. The mean (M) and standard error (m) for each indicator were used to determine the difference between the values of the indicators in the comparison groups, using Student's t-criteris. The difference between groups was considered statistically significant when $\mathrm{p}<0.05$.

\section{Results}

While examining 37 patients with LRP, an increase of proinflammatory cytokines in blood serum was observed - an increase in TNF- $\alpha$ content (by $58.8 \%, p=0.042$ ) and an increase in IL-1 $\beta$ (by $37.4 \%$, $\mathrm{p}=0.047$ ). At the same time, the estimation of serum content of anti-inflammatory cytokines revealed only a mild increase in the content of IL-4 $(9.81 \%, p=0.57)$ and a tendency to decrease the level of IL-10 (8.0\%, p $=0.68$ ), which are presented in Table 1 .

The analysis of cytokine profile of peripheral blood in patients with LRP, depending on the area of skin lesions (Table 2), showed that in patients with limited skin lesions the values of the studied cytokines did not significantly differ from those in the control group: TNF- $\alpha 6.98 \pm 1.24 \mathrm{pg} / \mathrm{mL}$ (in the control group $6.21 \pm 1.18 \mathrm{pg} / \mathrm{mL}, \mathrm{p}=0.66)$, IL-1 $4.98 \pm 0.54$ $\mathrm{pg} / \mathrm{mL}$ (in the control group $4.23 \pm 0.51 \mathrm{pg} / \mathrm{mL}, \mathrm{p}=$ 0.32 ), IL-4 $4.81 \pm 0.76 \mathrm{pg} / \mathrm{mL}$ (in the control group $3.77 \pm 0.43 \mathrm{pg} / \mathrm{mL}, \mathrm{p}=0.25)$, IL-10 $9.47 \pm 1.19 \mathrm{pg} / \mathrm{mL}$ (in the control group $8.25 \pm 1.09 \mathrm{pg} / \mathrm{mL}, \mathrm{p}=0.46$ ), as shown in Figure 1.

In patients with LRP with extensive skin lesions (Figure 1), the serum analysis of proinflammatory cytokines revealed a TNF- $\alpha 1.76$ times higher compared to the control group $(12.32 \pm 1.13 \mathrm{pg} / \mathrm{mL}$, in the control group $6.21 \pm 1.18 \mathrm{pg} / \mathrm{mL}, \mathrm{p}<0.001)$ and IL-1 1.61 times higher $(6.83 \pm 0.75 \mathrm{pg} / \mathrm{mL}$, in the control group $4.23 \pm 0.51 \mathrm{pg} / \mathrm{mL}, \mathrm{p}=0.01)$. It has also been found that TNF- $\alpha$ levels in patients with extensive LRP are 


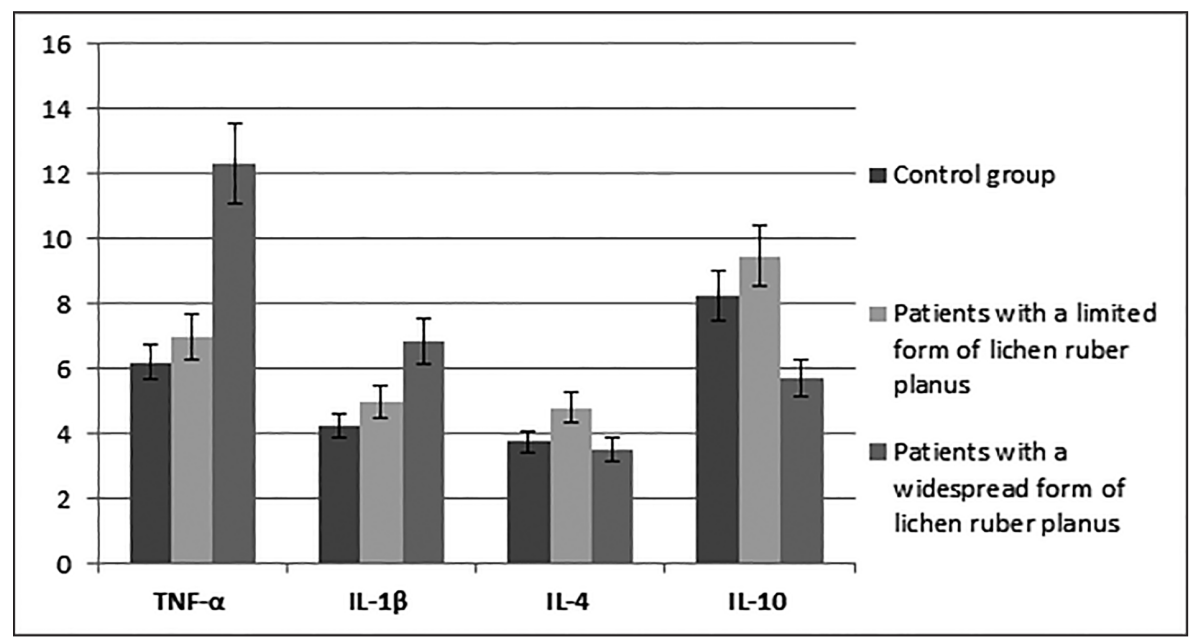

Figure. 1. The content of cytokines in the blood serum of patients with LRP with varying prevalence of the process on the skin $(\mathrm{M} \pm \mathrm{m}, \mathrm{pg} / \mathrm{mL})$.

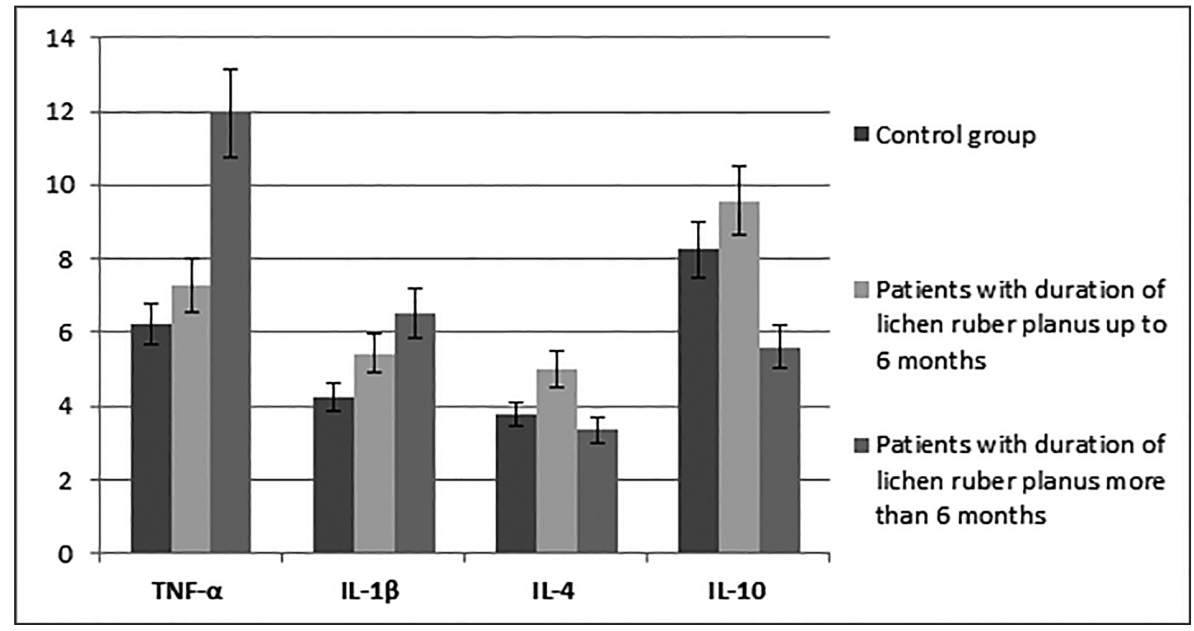

Figure. 2. The content of cytokines in the blood serum of patients with different duration of $\mathrm{LRP}(\mathrm{M} \pm \mathrm{m}, \mathrm{pg} / \mathrm{mL})$.

significantly higher than in those with a limited form of dermatosis - 1.76 fold $(12.32 \pm 1.13 \mathrm{pg} / \mathrm{mL}$, respectively, and $6.98 \pm 1.24 \mathrm{pg} / \mathrm{mL}, \mathrm{p}=0.003$ ). At the same time, it was found that the level of anti-inflammatory cytokine IL-10 in patients with extensive LRP was lower than in patients with a limited form of dermatosis 1.65 times (respectively: $5.72 \pm 0.78 \mathrm{pg} / \mathrm{mL}$ and $9.47 \pm$ $1.19 \mathrm{pg} / \mathrm{mL}, \mathrm{p}=0.01$ ), as shown in Figure 1 .

The comparative analysis of the level of the studied cytokines in the blood serum of patients with LRP with different duration of dermatosis showed that in patients with a chronic course (more than 6 months), as compared with the control group, there is a significant increase $(\mathrm{p}<0.05)$ of the level of proinflammatory cytokines - TNF- $\alpha$ by 1.92 times $(11.93 \pm 1.81 \mathrm{pg} / \mathrm{mL}$, in the control group $6.21 \pm 1.18 \mathrm{pg} / \mathrm{mL}, \mathrm{p}=0.017)$ and IL-1 $\beta$ by 1.61 times $(6.51 \pm 0,76 \mathrm{pg} / \mathrm{mL}$, in the control group $4.23 \pm 0.51 \mathrm{pg} / \mathrm{mL}, \mathrm{p}=0.021$ ) associated with the decrease in the anti-inflammatory cytokine IL-10 by 1.47 times $(5.61 \pm 0.72 \mathrm{pg} / \mathrm{mL}$, in the control group $8.25 \pm 1.09 \mathrm{pg} / \mathrm{mL}, \mathrm{p}=0.047$ ), as shown in Figure 2 .

Also, patients with LRP (over 6 months) showed a significantly higher level of proinflammatory cytokine TNF- $\alpha$ compared to patients with a duration of dermatosis up to 6 months: by 1.64 times $(11.93 \pm$ $1.81 \mathrm{pg} / \mathrm{mL}$ and $7.26 \pm 0.92 \mathrm{pg} / \mathrm{mL}, \mathrm{p}=0.025)$ associated with a decrease in anti-inflammatory cytokines: IL-4 1.48 times (respectively: $3.34 \pm 0.45 \mathrm{pg} / \mathrm{mL}$ and $4.97 \pm 0.63 \mathrm{pg} / \mathrm{mL}, \mathrm{p}=0.044$ ) and IL-10 1.70 times (respectively: $5.61 \pm 0.72 \mathrm{pg} / \mathrm{mL}$ and $9.58 \pm 1.17 \mathrm{pg} / \mathrm{mL}$, $\mathrm{p}=0.007$ ), as shown in Figure 2.

\section{Discussion}

The changes of the studied cytokines in peripheral blood of patients with LRP was characterized by 
an increase in the level of proinflammatory cytokines (TNF- $\alpha$, IL-1 $\beta$ ), associated with an insignificant increase or tendency to decrease of anti-inflammatory cytokines (IL-4 and IL-10). Interleukin-1 $\beta$ is a proinflammatory cytokine, which is produced mainly by macrophages, and is involved in reactive immune responses. The tumor-alpha necrosis factor belongs to proinflammatory cytokines and it is produced by different types of cells (monocytes-macrophages, Band T-lymphocytes); it is a mediator of a specific and non-specific response of the organism to the pathogens, and serves as an important link between the inflammatory and immune responses. It is known that IL-1 and TNF- $\alpha$ are synthesized in parallel in response to a stress reaction, and have the ability to induce each other's products ${ }^{14,16}$.

IL-4 is a regulatory anti-inflammatory cytokine, produced by mature cells and T-helper type II that inhibits the production of pro-inflammatory cytokines IL-1, IL-2, IL-6 and IL-8. Interleukin 10 is an anti-inflammatory cytokine produced by T-cells (Th2), and is an antagonist of certain cytokines; it suppresses the proliferative response of T-cells to antigens and mitogens, and also suppresses the production of proinflammatory cytokines, including secretion of activated monocytes of IL- $1 \beta$ and TNF- $\alpha^{14,16,18}$.

Thus, our results indicate that there is an imbalance in the serum content of pro- and anti-inflammatory cytokines in patients with LRP. Specifically, this is a statistically significant increase in the level of proinflammatory cytokines (TNF- $\alpha$, IL-1 $\beta$ ) and an insignificant elevation or tendency to decrease of anti-inflammatory cytokines (IL-4, IL-10). These changes were more significant in patients with extensive skin lesions comparing to patients with limited skin lesions. In addition, more significant changes of pro- and anti-inflammatory cytokines in patients with longer history of disease (more than 6 months) were detected. The results of the research indicate that the peculiarities of changes in the proinflammatory (TNF- $\alpha$, IL-1 $\beta$ ) and anti-inflammatory (IL-4, IL-10) cytokines in blood serum of patients with LRP with different clinical course may be one of the most important pathogenetic factors for the clinical manifestations - the spread of the process on the skin and the chronicity of LRP in such patients.

\section{Conclusions}

In patients with lichen ruber planus, changes of cytokine profile in the peripheral blood were observed. There was a significant increase in the level of proinflammatory cytokines - TNF- $\alpha$ (by $58.8 \%$, p $=0.042$ ) and IL-1 $\beta$ (by $37.4 \%, p=0.047$ ) compared to the control group, with unreliable changes in the levels of anti-inflammatory cytokines - only a mild increase in the content of IL-4 and the tendency to decrease in IL-10, respectively.

The magnitude of changes in the examined cytokines was dependent on the nature of the clinical progression of the lichen ruber planus. Significant changes in the content of the cytokines in the blood serum were observed for the patients with a widespread form of lichen ruber planus and the duration of the disease for more than 6 months comparing to those with the limited forms of the dermatosis and the duration of the disease for up to 6 months.

This finding indicates the significance of the cytokines in the regulation of inflammatory processes in the pathogenesis of lichen ruber planus. These findings report the importance in examining levels of pro- and anti-inflammatory cytokines as a criteria in the clinical evaluation of lichen ruber planus and the effectiveness of its treatment.

\section{Compliance with Ethics Requirements:}

"The authors declare no conflict of interest regarding this article"

"The authors declare that all the procedures and experiments of this study respect the ethical standards in the Helsinki Declaration of 1975, as revised in 2008(5), as well as the national law. Informed consent was obtained from all the patients included in the study"

"No funding for this study“

\section{References}

1. Schilling L, Vogt T. Lichen ruber planus. Der Hautarz. 2018; 69(2): 100-108.

2. Vogt T. Papulöse und lichenoide Erkrankungen. In Braun-Falco's Dermatologie, Venerologie und Allergologie. Springer, Berlin, Heidelberg. 2018: 703-719.

3. Mauskar M. Erosive lichen planus. Obstetrics and Gynecology Clinics. 2017; 44(3): 407-420.

4. Čanković M, Bokor-Bratić M, Novović Z. Stressful life events and personality traits in patients with oral lichen planus. Acta Dermatovenerologica Croatica. 2015; 23(4): 270-270.

5. Lajevardi V, Ghodsi SZ, Hallaji Z, Shafiei Z, Aghazadeh N, Akbari Z. Treatment of erosive oral lichen planus with methotrexate. JDDG: Journal der Deutschen Dermatologischen Gesellschaft. 2016; 14(3): 286-293.

6. Lopez-Jornet P, Martinez-Canovas A, Pons-Fuster A. Salivary biomarkers of oxidative stress and quality of life in patients with oral lichen planus. Geriatrics and Gerontology International. 2014; 14(3): 654-659.

7. Payeras MR, Cherubini K, Figueiredo MA, Salum FG. Oral lichen planus: focus on etiopathogenesis. Archives of Oral Biology. 2013; 58(9): 1057-1069.

8. Akram Z, Abduljabbar T, Vohra F, Javed F. Efficacy of low-level laser therapy compared to steroid therapy in the treatment of oral lichen planus: A systematic review. Journal of Oral Pathology $\mathcal{E}$ Medicine. 2018; 47(1): 11-17. 
9. Al-Maweri SA, Kalakonda B, Al-Soneidar WA, et al. Efficacy of low-level laser therapy in management of symptomatic oral lichen planus: a systematic review. Lasers in Medical Science. 2017; 32(6): 1429-1437.

10. Aly DG, Shahin RS. Oxidative stress in lichen planus. Acta Dermatoven APA. 2010; 19(1): 3-11.

11. Jang SH, Yun SJ, Lee SC, Lee JB. Lichen planus pemphigoides associated with chronic hepatitis $\mathrm{B}$ virus infection. Clinical and Experimental Dermatology. 2015; 40(8): 868-871.

12. Panchal FH, Ray S, Munshi RP, Bhalerao SS, Nayak CS. Alterations in lipid metabolism and antioxidant status in lichen planus. Indian Journal of Dermatology. 2015; 60(5): 439.

13. Stepanenko VI (ed): Dermatology, Venerology. Textbook. (Published in Ukrainian). Kyiv, KIM, 2013: 560.

14. Belova OV, Arion VY, Sergienko VI. The role of cytokines in the immunological function of the skin. (Published in Russia). Immunopathology, Allergology, Infectology. 2008; 1: 41-45.

15. Bonefeld CM, Geisler C. The role of innate lymphoid cells in healthy and inflamed skin. Immunol Lett. 2016; 179: 25-28.

16. Drannik GN, Drannik AG. Introduction to Clinical Immunology. (Published in Ukrainian). Kyiv, 2015: 200.
17. Sorokman TV, Sokolnyk SV, Babiy OR, et al. Immunological parameters and cortisol levels in children with atopic dermatitis. Arch Balk Med Union. 2018; 53(2): 210-216.

18. Kurchenko AI, Drannik GM, Reguretskaya RA. Immunophenotypic picture and cytokine profile of peripheral blood of patients with red flat lichen of the mucous membrane of the oral cavity in the stage of exacerbation. (Published in Ukrainian). Immunology and Allergology: Science and Practice. 2014; 1: 99-101.

19. Liu J, Shi Q, Yang S, et al. The relationship between levels of salivary and serum interleukin- 6 and oral lichen planus: A systematic review and meta-analysis. The Journal of the American Dental Association. 2017; 148(10): 743-749.

20. Reguretskaya RA, Kurchenko AI, Plastun OM. Cellular and cytokine profile of peripheral blood of patients with red flat lichen of the mucous membrane of the oral cavity. (Published in Ukrainian). Immunology and Allergology: Science and Practice. 2013; 1: 100-102.

21. Tavangar A, Ghalayani P, Boroujeni MA, Ghoreishian FS. Salivary levels of interleukin-8 in oral lichen planus and diabetic patients: a biochemical study. Dental Research Journal. 2017; 14(3): 209. 